\title{
Analysis of the Implementation of the Indonesian National Qualifications Framework Oriented Curriculum in the Mathematics Education Program of Universitas Negeri Medan
}

\author{
Yuliani Aruan', Edi Syahputra ${ }^{2}$, Edy Surya ${ }^{3}$ \\ ${ }^{1}$ Postgraduate Program in Universitas Negeri Medan, Indonesia \\ ${ }^{2,3}$ Universitas Negeri Medan, Indonesia
}

\section{Abstract}

This study aims to describe: 1) the implementation of the curriculum oriented to the Indonesian National Qualifications Framework (KKNI), 2) student responses to the six tasks required in the KKNI curriculum, 3) the quality of student performance and achievement with the implementation of the KKNI curriculum. This research is a descriptive qualitative research which aims to describe the implementation of the curriculum oriented to the Indonesian National Qualifications Framework (KKNI). Subjek in this study were undergraduate students1 in the first semester, three, and five mathematics education of UNIMED. The subjects who were subjected to in-depth interviews were randomly selected six students. Data obtained from the distribution of questionnaires and observations of the lecture process and in-depth interviews. The object of this research is the implementation of the KKNI curriculum, student responses, performance, and achievement oriented to the Indonesian National Qualifications Framework (KKNI). Based on data analysis, it is found that: 1) The implementation of the Indonesian National Qualifications Framework (KKNI) has not been carried out optimally or well in the mathematics education lecture process, 2) Students have a positive response to the application of the Indonesian National Qualifications Framework (KKNI), 3) Performance Quality is quite good in the application of the Indonesian National Qualifications Framework (KKNI), 4) Students' learning achievement is quite low in the application of the Indonesian National Qualifications Framework (KKNI).
Keywords

analysis; curriculum; Indonesian National Qualifications

Framework (KKNI)

\section{Introduction}

Demands increase towards adequate human resources requires the College Heigh should be prepared of all the good aspects of aspects of the facilities and infrastructure, aspects of stakeholder education and especially the learning aspect. Good learning is arranged in a systematic learning design. The learning design can not be separated from the curriculum as a guide in the preparation process (Monalisa, Fatahillah, Murtikusuma, 2017: 41).

Curriculum have that effect in Indonesia today is is the curriculum of Indonesian national qualifications framework. In the KKNI document (2015) it is stated that "The Indonesian National Qualifications Framework (KKNI) is a form of embodiment of the quality and identity of the Indonesian nation related to the national education system, the national job training system and the national equality assessment system, which is owned by Indonesia to produce human resources from the learning achievements possessed by every 
Indonesian worker in creating quality work and contributions in their respective fields of work ". However, a number of data are also presented in the findings of Maksum (2016) " Based on PD-Dikti data on March 26, 2015, the number of universities in Indonesia is 4,268, consisting of 365 PTNs and 3,903 PTS, with a total study program of 21,864, meanwhile the number of students by 7, 4 million, consisting of 2.8 million in state and 4.6 million in the PTS. The number of lecturers with Doctoral degrees is 22,430 (12\%) and those who have professor academic positions are 4,948 (3\%) of the total 184,551 lecturers. Compare this with the number of universities in America, namely 4,599 with 21 million students. In terms of quantity, it is possible that what we have is more than enough. However, in terms of quality, it still leaves a serious problem.

In an effort to qualify higher education graduates in Indonesia, the Government has issued Presidential Decree No. 8 of 2012 concerning the Indonesian National Qualifications Framework (KKNI) which is the reference in the preparation of the learning outcomes of graduates from each level of education nationally.

The basic principle developed in the IQF is to assess a person's performance in scientific aspects, expertise and skills according to learning outcomes obtained through the process of education, training or experience that has been surpassed, which is equivalent to qualification descriptors for a certain level .

Based on the Presidential Decree no. 8 of 2012 and Permendikbud RI no. 73 of 2013 which requires universities including the mathematics education program of UNIMED to redesign with the reason for the logic of globalization, and also so that the quality is the same as foreign universities, the curriculum must use a national qualification framework which in Indonesia is called the Indonesian National Qualifications Framework (Rakhmadi, 2016: 4). The KKNI-based learning process is expected to be a solution in order to develop the learning process in Indonesia towards a better direction (Thamrin, 2017: 1).

It was found that the scores for the six assignments were smaller than the scores for the middle semester and the end-semester examinations. While the process of completing the six tasks contained in the KKNI assignments takes quite a long time, namely one semester or around 16 weeks, it can even exceed the promised time so that it has an impact on the students' lack of seriousness when completing the six tasks contained in the KKNI, resulting in not maximal results of KKNI assignments, also impacting on decreased achievement.

Students experience problems when working on six assignments in certain subjects, because some lecturers provide different assignment formats. As a result, students will carry out these assignments only based on their own thoughts and opinions, especially mathematics courses whose overall concepts are abstract so that students find it difficult to formulate and complete them in the six assignments format contained in the Indonesian National Qualifications Framework (KKNI).

\section{Review of Literatures}

\subsection{Definition of Mathematics}

According Jhonson and Myklebus (Rahman, 2009: 252 ) mathematics is the language of symbols to express the practical function relationships of quantitative and spatial whereas theoretical function is to facilitate thinking. Mathematics is a product of human intellectual thinking. Intellectual thinking can be driven from mere thinking problems or from problems related to everyday real life. Mathematics is thus referred to as the real life of everyday people. 
One of the mathematical skills that students must possess and achieve is problem solving. Problem solving is very close to mathematical characteristics. Problem solving (problem solving) is a process carried out to reach logical conclusions based on knowledge relating to facts and various relevant sources (Pohan, 2020).

\subsection{Basic Curriculum Concepts}

According to Good (1959) (Hidayat, 2011: 8 ) the curriculum is a general plan regarding the content or certain material of instruction that schools must meet qualifications or certification and can continue to be professional or vocational midwives .

\subsection{Implementation of the Indonesian National Qualifications Framework ( KKNI)}

According to the Regulation of the Minister of Education and Culture of the Republic of Indonesia Number 73 of 2013, what is meant by KKNI in the field of Higher Education is "a qualification ranking framework that can juxtapose, equalize, and integrate learning outcomes from non-formal education, informal education, and / or work experience into types and higher education level ".

\subsection{Student Response}

Response or perception or response is the meanings of vision results including responses about the overall environment in which the individual is and is raised, and conditions are stimuli and perceptions. After receiving the stimulus, then there is a selection related to interpretation, and then a permanent memory response is formed called mental-epsesentation. (Sardiman, 2007: 74).

\subsection{Performance}

Lawer and Porter (1976) define performance as a successful achievement that a person gets from his job, while a person's performance level is a measure of how successful a person is in doing his job.

\subsection{Learning Achievement}

Student learning achievement is student results achieved after going through some of the learning process of acquisition of knowledge of students by subjects who typically indicated by test scores or grades given number of lecturers. According to Sitorus (2020) The success of a teacher implementing a learning strategy is very dependent on the teacher's ability to analyze the existing learning conditions, such as learning objectives, student characteristics, learning resource constraints, and characteristics of the field of study.

\section{Research Methods}

This research was conducted at FMIPA UNIMED. The research subjects involved three classes and lecturers in the three undergraduate mathematics education courses (S1). The criteria for taking subjects who were subjected to interviews in this study using purposive sampling technique (Salim and Syahrum, 2016: 142). The object of this research is the analysis of the implementation of the curriculum oriented to the Indonesian National Qualifications Framework (KKNI) which is obtained from the results of observations, questionnaires, interviews, and documentation.

This study includes a descriptive study using a qualitative approach (Raco, 2010: 67) is a study which aims to provide a snapshot of a problem, symptoms, facts, events, and reality is 
broad and deep in broad and deep in order to obtain a new understanding, and the type of descriptive research (Gulo, 2010: 19). Data analysis using Miles and Huberman model, namely: 1) Reduction of Data, 2) Presentation of Data, and 3) Conclusion.

\section{Discussion}

Implementation of the curriculum oriented to the Indonesian National Qualifications Framework (KKNI) has not been carried out optimally because there are some professors who do not give six tasks in KKNI, so that has been prepared in RPS and SAP have not not entirely implemented, also found that the concept of the assignment of different KKNI cause understanding of the concept curriculum is not clear KKNI.

Student responses to the six tasks contained in the KKNI curriculum in the mathematics education program are divided into three indicators. First, with scores questionnaire conclude $76 \%$ of students are quite happy complete six assignments contained in the curriculum KKNI. Second, with a questionnaire score of $74 \%$, it was concluded that students were serious enough when completing the six tasks contained in the KKNI curriculum. Third, scores questionnaire $77 \%$ concluded that all six tasks contained in the curriculum KKNI provide considerable benefit both, especially those in developing a writing scientific papers and thesis preparation in the next days. Overall it is concluded that students give a fairly good response incompleting the six tasks contained in the KKNI curriculum in the mathematics education program with a score of $76.6 \%$.

The quality of performance on the six tasks contained in the KKNI curriculum in the mathematics education program is divided into four indicators. First, with a score of $82 \%$, it can be concluded that the quality of student work is good in completing the six tasks contained in the KKNI curriculum. Second, with a score of $80 \%$, it is concluded that students have a good number of work results when completing the six tasks in KKNI curriculum. Third, with a score of $75 \%$, it was concluded that students had sufficient time to complete the six KKNI curriculum tasks. Fourth, with a score of $84 \%$, it can be concluded that student cooperation between peers, both individuals and groups of students, gets good results. And overall that the student's performance was good in completing the six tasks contained in the KKNI curriculum in the mathematics education program with a score of $82 \%$. This is evidenced by one of the following student works:

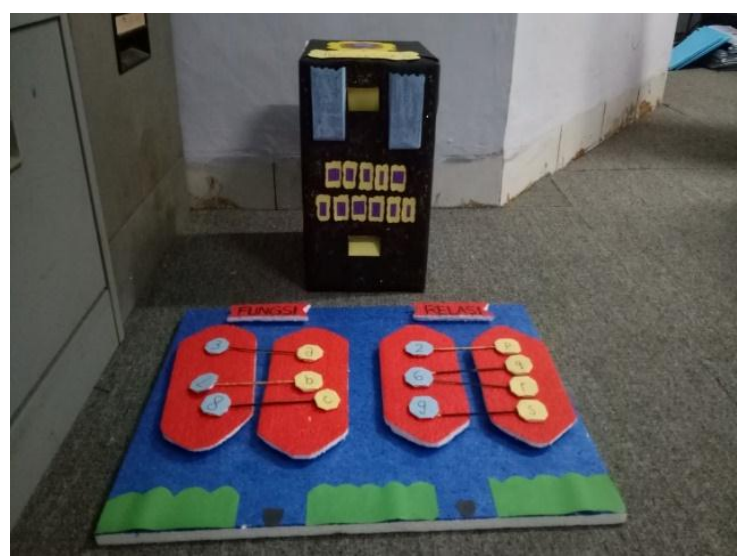

Figure 1. Student Work for Project Assignments 
The picture above is one of the group assignments from student project assignments that will be exhibited at the campus annual final event. This shows that the quality of student work in completing the six KKNI assignments is quite good from the seriousness of students in realizing the concept of functions and relations into a real work and can be used for practical and direct learning. The learning achievement of students is quite low due to the workload a lot with short turnaround time and also the format of the six different KKNI tasks causes more students to focus on finishing all six tasks IN KKNI than mastering course materials.

\section{Conclusion}

\subsection{Conclusion}

1. The implementation of the Indonesian National Qualifications Framework (KKNI) has not been carried out optimally in the process of mathematics education program

2. Students have a positive response to the application of the Indonesian National Qualifications Framework (KKNI)

3. The quality of student performance is quite good in applying the Indonesian National Qualifications Framework (KKNI).

4. Students' leaming achievement is quite low in the application of the Indonesian National Qualifications Framework (KKNI).

\subsection{Suggestion}

1. For a more maximal and better implementation of the KKNI curriculum, it is necessary to discuss the concept of assignments or assignment guidelines for the six tasks contained in the KKNI in one group of subjects and in certain subjects in order to forward the draft assignment KKNI specifically readily understood by students and professors.

2. In implementing KKNI curriculum expected that professors presses and encourage students to produce a work of real and certainly would me mprovide the benefits of the practice of fieldwork in each student.

\section{References}

Abdurrahman, M., 2009. Pendidikan Bagi Anak Berkesulitan Belajar. Jakarta: Rineka Cipta.

Amiluddin, R., Sugiman, S., Pengaruh Problem Posing dan PBL Terhadap Prestasi Belajar, dan Motivasi Belajar Mahasiswa Pendidikan Matematika. Jurnal Riset Pendidikan Matematika (Online), Vol. 3, No. 1, Mei 2016.

Afifuddin , Saebani, A., B., 2009. Metodologi Penenlitian Kualitatif. Bandung: Pustaka Setia.

Anderson, J., 2009. Mathematics Curriculum Development and the Role of Problem Solving, ACSA Conference, (online), diakses tahun 2009.

Casmini, Evaluasi dan Peninjauan Kurikulum BKI Berbasis KKNI. Jurnal Hisbah (Online), Vol 11, No. 1, Juni 2014.

Chan, S., M., Sam, T., 2005. Kebijakan Pendidikan Era Otonomi Daerah. Jakarta: Raja Grafindo Persada.

Choi, M., K., Park, J., H., 2013. A Comparative Analysis of Geometry Education on Curriculum Standards, Textbook Structure, and Textbook Items between the U.S. 
and Korea, Eurasia Journal of Mathematics, Science \& Technology Education, (Online), ISSN: 1305-8223, diakses 20 November 2013.

Direja, C., A., 2017. Studi Implementasi Kurikulum Berbasis KKNI Pada Program Studi S1 Ilmu Komunikasi Universitas Informatika dan Bisnis Indonesia. Jurnal Edutech. Vol. 16, No. 2, diakses juni 2017

Fahmi, A., Syahputra, E., Rajagukguk, W., R., Peningkatan Kemampuan Penalaran dan Komunikasi Matematik Siswa Melalui Model Pembelajaran Berbasis Masalah Berbantuan Geogebra di Kelas VIII SMP Negeri 1 Samudera, Jurnla Pendidikan Matematika, (Online), Paradikma Vol. 9 No. 1, diakses 1 April 2016.

Hajer, M., Noren, E., 2017. Teachers' Knowledge about Language in Mathematics Professional Development Courses: From an Intended Curriculum to a Curriculum in Action. EURASIA Journal of Mathematics Science and Technology Education, (online), ISSN: 1305-8223, diakses 20 maret 2017.

Hasratuddin. 2015. Mengapa Harus Belajar Matematika?. Medan : Perdana Publishing.

Hidayat, R., 2011. Pengantar Sosiologi Kurikulum. Jakarta : Raja Grafindo Persada.

Hutabarat, A., B., Evaluasi Kebijakan Kerangka Kualifikasi Nasional Indonesia Bidang Pendidikan Tinggi. Academia Edu (Online).

Idi, A., . Pengembangan Kurikulum: Teori \& Praktik. Jogjakarta: Ar-Ruzz Media.

Jono, A., A., 2016. Studi Implementasi Kurikulum Berbasis KKNI Pada Program Studi Pendidikan Bahasa Inggris di LPTK Se-Kota Bengkulu. Jurnal Manhaj. Vol. 4, No. 1, diakses April 2016.

Khairiah. 2015. Pengaruh Impementasi Kurikulum Berbasis KKNI Terhadap Peningkatan Mutu Pendidikan PTAIN. Jurnal NUANSA, (online), Vol. VII No. 2, diakses Desember 2015.

Keputusan Menteri Pendidikan Nasional RI No. 045/U/2002 Tetang Kurikulum Inti Pendidikan Tinggi. Jakarta: Menteri Pendidikan Nasional.

Kisbiyanto. 2016. Manajemen Pengembangan Kurikulum Sistem KKNI di PGMI. Jurnal Quality, (online), Vol. 4, No. 2, diakses tahun 2016.

Kusmaeni, E., Pengaruh Metode Pembelajaran Variasi Terhadap Prestasi Mahasiswa Manajemen Pada Mata Kuliah Akuntansi Pengantar 1 dengan Motivasi Sebagai Variabel Moderating. STIESI Surabaya. 2016

Krismiyati. 2017. Pengembangan Sumber Daya Manusia dalam Meningkatkan Kualitas Pendidikan di SD Negeri Inpres Angkasa Biak. Jurnal Office, (online), Vol. 3 No. 1, diakses tahun 2017.

Maksum, A. 2015. Kurikulum dan Pembelajaran di Perguruan Tinggi: Menuju Pendidikan yang Memberdayakan. Jurnal Reserac Gate (Online), diakses 12 Juni 2016.

Menteri Pendidikan dan Kebudayaan. Panduan Penyusunan Capaian Pembelajaran Lulusan Program Studi. Jakarta.

Miliyawati, B., Kurikulum dan Pembelajaran Matematika di Jepang Serta Perbandingannya dengan di Indonesia. Jurnal Pendidikan Matematika Kalamatika (Online), Vol. I, No, 1, diakses April 2016.

Murtafiah, W., Sanusi, Suprapto, E., Pengembangan Bahan Ajar Berorientasi KKNI untuk Meningkatkan Scientific Approach pada Mata Kuliah Evaluasi dan Proses Pembelajaran Matematika. Jurnal Penelitian Pendidikan (Online), Vol. 8, No. 1, diakses Juni 2016, pp. 1189-1249.

Nasution, R., P., Surya, E., Syahputra, E., Perbedaan Peningkatan Kemampuan Berpikir Kreatif Matematis dan Kemandirian Belajar Siswa pada Pembelajaran Berbasis Masalah dan Pembelajaran Konvensional di SMPN 4 Padangsidempuan. Jurnal Paradikma (Online), Vol. 8, Nomor 3, Desember 2015. 
Peraturan Menteri Pendidikan dan Kebudayaan (Permendikbud No. 73 Tahun 2013 Tentang Penerapan Kerangka Kualifikasi Nasional Indonesia Bidang Pendidikan Tinggi. Jakarta: Menteri Pendidikan dan Kebudayaan.

Peraturan Menteri Pendidikan dan Kebudayaan Nomor 44 Tahun 2015 Tentang Standar Nasional Pendidikan Tinggi (SNPT) dan kurikulum berorientasi KKNI. Jakarta: Menteri Pendidikan dan Kebudayaan.

Peraturan Menteri Pendidikan dan Kebudayaan No. 49 Tahun 2014 tentang Standar Nasional Pendidikan Tinggi. Jakarta : Menteri Pendidikan dan Kebudayaan

Peraturan Presiden (Perpres) Republik Indonesia No. 8 Tahun 2012 Tentang Kerangka Kualifikasi Nasional Indonesia. Jakarta: Sekretariat Kabinet.

Peraturan Pemerintah Republik Indonesia No. 17 Tahun 2010_Tentang Pengelolaan dan Penyelenggaraan Pendidikan. Jakarta: Sekretariat Negara.

Poerwati, T., Pengaruh Perilaku Belajar dan Motivasi Terhadap Prestasi Akademik Mahasiswa Akuntansi di Universitas STIKUBANK (UNISBANK) Semarang, Jurnal UNPAD. Vol. 8, No. 16, 2010.

Pohan, A.M., Asmin, and Menanti, A. (2020). The Effect of Problem Based Learning and Learning Motivation of Mathematical Problem Solving Skills of Class 5 Students at SDN 0407 Mondang. Budapest International Research and Critics in Linguistics and Education (BirLE) Journal Vol 3 (1): 531-539.

Program Pascasarjana. 2016. Panduan Pemberian Tugas dalam Perkuliahan (Dokumen 28). Medan : UNIMED.

Rakhmadi, F., A., 2016. Struktur Kurikulum Berbasis KKNI . Jurnal UIN Sunan Kalijaga, (online).

Rivai, V. 2005. Manajemen Sumber Daya Manusia Untuk Perusahaan. Jakarta : PT. Gravindo Persada Indonesia.

Salim. Syahrum. 2016. Metodologi Penelitian Kualitatif. Bandung: Citapustaka Media

Schummer, S., Millan, M., J., 2001. Research and Education: A Conceptual Introduction, New York: Longman.

Setiawan. D., 2016. Pengembangan Kurikulum Pendidikan Berbasis KKNI dan Berwawasan Kebangsaan sebagai Program Dukungan Pembangunan Berkelanjutan di Bidang Pendidikan. Makalah disajikan dalam Seminar Nasional Pendidikan IlmuIlmu Sosial Membentuk Karakter Bangsa Dalam Rangka Daya Saing Global, Fakultas Ilmu Sosial UNM, Makassar, 29 Oktober.

Setiawan. D., 2017. Pengembangan Model Kurikulum Berorientasi KKNI di Fakultas Ilmu Sosial Universitas Negeri Medan. Prosiding Seminar Nasional Tahunan Fakultas Ilmu Sosial UNIMED, Vol. 1, No. 1201. 2017.

Sitorus, L.S., Mardianto, and Matsum, H. (2020). Development of Powerpoint-Based Learning Media on Learning Aqeedah Morals. Budapest International Research and Critics in Linguistics and Education (BirLE) Journal Vol 3 (2): 958-964.

Sugiyomo. 2013. Penelitian Kuantitatif dan $R \& D$. Bandung : Alfabeta

Sulistyastuti, D., R.. (2012). Implementasi Kebijakan Publik: Konsep dan Aplikasinya di Indonesia. Yogyakarta: Gava Media.

Susanto, A., 2013. Teori Belajar dan Pembelajaran di Sekolah Dasar. Jakarta: Kencana Prenada Media Group.

Sutrisno. Suyadi. (2016). Desain Kurikulum Perguruan Tinggi Mengacu Kerangka Kualifikasi Nasional Indonesia. Bandung: Ikapi

Tim KKNI. 2015. Dokumen Kerangka Kualifikasi Nasional Indonesia. Jakarta: Ristekdikti. 
Thamrin, Model Pengembangan KBK Berorientasi KKNI dan Pendidikan Karakter Budaya Akademik di Fakultas Ekonomi Universitas Negeri Medan. Jurnal Niagawan (Online), Vol. 6, No 2, Oktober 2017.

Undang-Undang Republik Indonesia No. 12 Tahun 2012 tentang Pendidikan Tinggi. Jakarta : Republik Indonesia.

Waseso, P., H., Hidayat, S., M., Penerapan Kurikulum Berbasis KKNI pada Prodi PGMI Unsiq Jawa Tengah. Jirnal Ilmiah PGMI (Online), Vol. 3, No. 1, Juni 2017.

WK., R., M., Naomi, P., Pengaruh Motivasi Diri Terhadap Kinerja Belajar Mahasiswa. Portal Jurnal (Online). Vol. 7 No. 7, Oktober 2017.

Yamin, M., 2012. Panduan Manajemen Mutu Kurikulum Pendidikan: Panduan Lengkap Tata Kelola Kurikulum Efektif. Jogjakarta : Diva Press 